\title{
COMPARISON OF TECHNIQUES USED FOR FUNCTIONAL EVALUATION OF PELVIC FLOOR MUSCLES
}

\section{Comparação das técnicas utilizadas para avaliação funcional dos músculos do assoalho pélvico}

\section{Comparación entre las técnicas de evaluación funcional de los músculos del suelo pélvico}

\author{
Christiane Kelen Lucena da Costa \\ Federal University of Rio Grande do Norte (Universidade Federal do Rio Grande do Norte - UFRN) - Natal (PB) - Brazil
}

\section{Maria Helena Constantino Spirydes}

Federal University of Rio Grande do Norte (Universidade Federal do Rio Grande do Norte - UFRN) - Natal (PB) - Brazil

Maria Bernardete Cordeiro de Sousa

Federal University of Rio Grande do Norte (Universidade Federal do Rio Grande do Norte - UFRN) - Natal (PB) - Brazil

\begin{abstract}
Objective: To identify and discuss techniques for evaluation of pelvic floor muscles (PFM) focusing on the most used and accessible techniques in health care. Methods: This is a quantitative exploratory and descriptive applied research. Data were collected from March to June 2016 at a higher education institution in the city of João Pessoa, Paraíba, Brazil. Initially, 31 healthy young women were submitted to pelvic floor evaluation using the following methods: PERFECT, vaginal cones, and perineometry using Perine and Peritron. The participants then performed exercises to strengthen PFM. The variables measured by the different methods were also recorded 30 and 60 days after the start of the program. ANOVA was used for repeated measures and Spearman's correlation test was used for the evaluation instruments with significance set at 5\%. Results: The functional evaluation using all the methods was adequate in the PFM evaluation. In the digital palpation (PERFECT), the endurance response $(E)$ was positively correlated to Perina $(\mathrm{rho}=0.688)$ and vaginal cones $(\mathrm{rho}=0.571)$, and muscle strength (P) was positively correlated to the Peritron technique ( $r$ o=0.506). Conclusion: There are several ways to evaluate PFM function and all of them provide sensory feedback to the patient. Given the low costs of digital palpation, the introduction of this technique into women's health services is likely to improve women's quality of life.
\end{abstract}

Descriptors: Pelvic floor; Muscle Strength; Women's Health.

\section{RESUMO}

Objetivo: Identificar e discutir técnicas de avaliação dos músculos do assoalho pélvico (MAP) enfocando as mais usadas e acessíveis na assistência à saúde. Métodos: Trata-se de um estudo exploratório, com pesquisa descritiva e aplicada, e abordagem quantitativa. A coleta de dados foi realizada no periodo de março a junho de 2016 em uma instituição de ensino superior da cidade de João Pessoa$P B$. Inicialmente, 31 adultas jovens e saudáveis foram submetidas à avaliação do assoalho pélvico utilizando os métodos: PERFECT, cones vaginais, perineometria com Perina e Peritron. Em seguida, as participantes se submeteram a exercícios para fortalecer os MAP. As variáveis quantificadas pelos diferentes métodos também foram registadas 30 e 60 dias após o início do programa. Aplicou-se ANOVA para medidas repetidas e teste de correlação Spearman 's em 5\% entre os instrumentos de avaliação. Resultados: A avaliação funcional com todos os métodos foi adequada na avaliação dos MAP. Na palpação digital (PERFECT), a resposta de resistência (E) mostrou correlação positiva com o Perina (rho=0.688) e com os cones vaginais (rho=0.571), por sua vez, a força muscular $(P)$ teve correlação positiva com a técnica do Peritron (rho= 0.506). Conclusão: Várias são as maneiras de avaliar a função do MAP e todas promovem feedback sensorial ao paciente. Com relação aos baixos custos da palpação digital, a introdução dessa técnica em serviços de saúde feminina provavelmente proporcionará melhora da qualidade de vida das mulheres.

Descritores: Assoalho pélvico; Força muscular; Saúde da Mulher. 


\section{RESUMEN}

Objetivo: Identificar y discutir técnicas de evaluación de los músculos del suelo pélvico (MSP) con énfasis en las técnicas más utilizadas y asequibles para el cuidado de la salud. Métodos: Estudio exploratorio de abordaje descriptivo y cuantitativo aplicado en investigación. La recogida de datos se dio entre marzo y junio de 2016 en una institución de educación superior de la ciudad de João Pessoa, PB, Brasil. A principio fue realizada la evaluación del suelo pélvico en 31 mujeres jóvenes y saludables con los siguientes métodos: PERFECTO, conos vaginales, perineometria con Perine y Peritron. Después las participantes realizaron ejercicios para fortalecimiento de los MSP. Las variables cuantificadas por métodos distintos fueron también registradas en 30 y 60 días después del inicio del programa. Se aplicó la ANOVA para medidas repetidas y la correlación de Spearman fue aplicada en el 5\% de los instrumentos de evaluación. Resultados: La evaluación funcional con todos los métodos ha sido adecuada para la evaluación de los MSP. En la palpación digital (PERFECTO) la respuesta de resistencia (E) mostró una correlación positiva con la Perina (rho $=0.688)$ y los conos vaginales (rho $=0.571)$ y la fuerza del músculo $(P)$ tuvo una correlación positiva con la técnica Peritron (Rho = 0.506). Conclusión: Hay varias maneras de evaluar la función de los músculos del suelo pélvico y promover la respuesta sensorial al paciente. El método PERFECTO permite cuantificar la intensidad, el número de contracciones, ambos rápido y lento, así como la duración de la contracción de la musculatura perineal y, por lo tanto, aunque sea un método barato, ha sido sensible y especifico para el objetivo estimado. Respecto los bajos costes de la palpación digital, la introducción de esa técnica en los servicios de salud para mujeres probablemente puede mejorar la calidad de vida de las mujeres.

Descriptores: Diafragma Pélvico; Fuerza Muscular; Salud de la Mujer.

\section{INTRODUCTION}

Evaluation of the pelvic floor muscles (PFM) is essential to identify its functionality. The literature shows that its malfunctioning can affect women's quality of life through comorbidities such as urinary and fecal incontinence, sexual dysfunction and pelvic pain ${ }^{(1,2)}$.

The PFM consists of two types of fibers: type I fibers (tonics) and type II fibers (phasic). Type I fibers ( $70 \%$ of the pelvic floor musculature) are slow contraction fibers causing prolonged contractions with little force and are responsible for the antigravitational action of the pelvic floor muscles. On the other hand, type II fibers contract quickly and produce force in rapid contraction, being recruited during a sudden increase in abdominal pressure, thus contributing to an increase in urethral closure pressure $^{(3)}$.

PFM dysfunctions are non-life-threatening conditions, but cause considerable morbidity. They can severely affect patients' quality of life, promoting physical, social, occupational and/or sexual limitations ${ }^{(4)}$.

Pelvic Floor Dysfunction (PFD) affects millions of women around the world, leading many to live with a precarious health condition and lack of specialized treatment. An increased prevalence of predisposing factors, such as obesity and aging, is contributing to the rise of PFD with escalating hospital and resource $\operatorname{costs}^{(5)}$. The reduction of PFM strength is an etiological factor in several diseases, such as organ prolapses, sexual dysfunctions, urinary incontinence, and others ${ }^{(6)}$.

The prevalence of prolapses in women between 20 and 59 years old is $30.8 \%$. Approximately $20 \%$ of sexually active women complain of chronic pelvic pain. It is estimated that $50 \%$ of women will experience urinary incontinence at some point in their life cycle and the prevalence of sexual dysfunction varies. The decline in the rate of estrogen associated with menopause has been considered a factor responsible for the high prevalence of urinary incontinence in older women and it is probable that there will also be important repercussions in the sexual life and quality of life of women ${ }^{(7)}$. This fact raises the need to evaluate and to train the PFM to prevent these dysfunctions.

Methods for evaluating the strength and the endurance of the PFM are subjective transvaginal digital palpation (e.g., PERFECT) and objective methods such as Perina ${ }^{\circledR}$ and Peritron ${ }^{\circledR}$ perineometry ${ }^{(8)}$.

Digital vaginal palpation applying the PERFECT scheme is used to assess the contractile components of PFM. The Perina biofeedback technique consists of a perineometer with a device that displays biological signals during voluntary contraction of the FPM, which are transmitted to the woman by auditory and/or visual cues, allowing awareness and correct contraction of the pelvic muscles $^{(9)}$.

Another perineometer (Peritron ${ }^{\circledR}$ ) registers the strength of PFM contractions through numerical sensing, which can range from 0.1 to $300 \mathrm{~cm}$ of water $(\mathrm{cmH} 2 \mathrm{O})$. Vaginal cones are also used to assess pelvic floor function and are based on stimulating the recruitment of the pubococcygeal and external anal sphincter muscles, which must retain heavier weights progressively. Vaginal cones promote more specific and effective muscle contractile activity, since the patient must contract their pelvic floor muscles to keep them in the vagina ${ }^{(10)}$.

It is important to note that the female pelvic floor is composed of a set of skeletal muscles. The levator ani muscle forms the main structure and is composed of the pubococcygeus, iliococcygeus, and puborectalis muscles. These three muscles are responsible for providing support to the static and dynamic internal pelvic organs and for the closure of the urethral sphincter, allowing urinary and fecal continence ${ }^{(11)}$. 
It is essential to preserve muscle strength and function in order to maintain their support functions (sphincter and sexual) and the position of the bladder neck. In women, urinary retention forces are vulnerable because of the short urethra and risk factors such as obstetric trauma, nerve injury to the pudendal nerve, fascia and/or pelvic floor muscles, in addition to the morphological and functional changes resulting from advancing age, menopause and consequent hormonal changes.

These factors can lead to weakening and functional disharmony in these muscles ${ }^{(12)}$. It is believed that strengthening the pelvic floor muscles in women, especially the ischiocavernosus and bulboespongiosus muscles, and having inserts in the cavernous body of the clitoris, impact sexual function, assisting in the stages of arousal and orgasm ${ }^{(13)}$. Some factors also explain the decrease in sexual complaints after these muscles have been trained, such as the fact that the orgasmic response of women is a sensorimotor reflex that promotes contractions of the perineal muscles during orgasm. Furthermore, training these muscles also produces an increase in pelvic vascularization and clitoral sensitivity, which optimizes arousal and lubrication. Increased blood flow and pelvic mobility also potentiate the genital and orgasmic excitement of women. Studies have also found an improvement in sexual desire, orgasm and performance during sex between women who underwent kinesiotherapy ${ }^{(13)}$.

A series of targeted exercises for the pelvic floor muscles were developed, performed with voluntary contraction that causes urethral closure, thus strengthening the perineal muscles ${ }^{(14)}$. Rehabilitation of the pelvic floor muscle through these exercises helps stabilizing the urethra by increasing pelvic floor muscle strength ${ }^{(15)}$.

Approximately $30 \%$ of women are unable to contract their pelvic floor muscles at initial assessment. Thus, individual awareness and correct muscle contraction are essential before starting treatment ${ }^{(10)}$.

Educational interventions that promote reflection and bring clarifications on the PFD are necessary for improving knowledge in the general population. Health professionals, particularly those in primary health care services, also need information about the impact of PFD on quality of life, its management and treatment in order to provide adequate care to those seeking help ${ }^{(16)}$.

Considering the importance of good PFM functionality for women's health and the variety of techniques existing to evaluate their performance, this study aims to identify and discuss some of the most commonly used techniques that are more accessible in public health facilities. Accordingly, it provided an overview of four methods that assess the function and strength of these muscles, discussing the responsiveness, reliability and validity of the results and their correlations across an exercise program to increase the strength of these muscles.

\section{METHODS}

This is a quantitative descriptive applied research. The population consisted of sexually active female students from a private university of the city of João Pessoa, Northeastern Brazil, and the study was conducted from March to June of 2016.

The sample consisted of 31 young adults who volunteered to participate in the study and met the following inclusion criteria: being heterosexual, aged 19 to 35 years; having a stable partner for the last six months and being at least 6 months postpartum; having had sex in the past six months; being clinically normal, and providing their informed consent. The study used convenience sampling. The population was composed of 60 female students but only 31 accepted to participate in the study and met the inclusion criteria. Before starting the intervention, a lecture on the research was carried out and a sociodemographic questionnaire was administered. The evaluations were carried out by a physiotherapist in a reserved room in the Physical Therapy Laboratory at the University.

Subjects were informed of the importance of the PFM exercise program and were asked to record the exercises performed. PFM evaluation was conducted in three phases: Phase 1 (before the intervention), Phase 2 (one month after intervention) and Phase 3 (two months after intervention).

Functional evaluation of the pelvic floor was performed by displaying the external genitalia and verifying the presence or absence of visible voluntary contraction of the muscles after a verbal command. The pelvic floor was then assessed by the PERFECT classification. The PERFECT method (Power, Endurance, Repetition, Fast contractions, Every Contraction Timed) was developed to assess the primary components of PFM contractility via digital palpation ${ }^{(16)}$.

In addition to digital palpation assessment, Peritron ${ }^{\mathrm{TM}}(9300+)$ from Australia and Biofeedback (Perina ${ }^{\circledR}$ Quark) perineometers were used. These tools provide an objective assessment of muscle function by determining the value of the pressure. Peritron and Biofeedback evaluate PFM in pressure units $\left(\mathrm{cmH}_{2} \mathrm{O}\right.$ and $\mathrm{mm}_{2} \mathrm{O}$, respectively).

Vaginal cones (Quark) are small anatomically-shaped capsules made of resistant and relatively heavy materials, whose weight ranges from 20 to 70 grams. Perineal muscle strength was determined after introducing progressively heavier vaginal cones into the vaginal canal. Participants were asked to perform perineal contraction to measure the maximum weights that they were able to retain.

The PFM strengthening program consisted of performing in-home exercises twice a week, after an explanation of their importance and expected effects. The exercises should be performed according to the instructions in the booklet delivered. Additionally, a booklet was given to each participant containing drawings showing the execution of the exercises, as well as a form to record daily activities. After 4 and 8 weeks, all participants were reevaluated using PERFECT, Peritron, Perina and vaginal cone procedures. 
When consistent best performance of pelvic floor muscle function was achieved after 4 weeks, the exercise progressed to higher strength levels. The exercises were adjusted to increase contraction time and number of repetitions, emphasizing both the slow (tonic) and fast (phasic) muscle fibers.

In order to evaluate the performance of participants in relation to the exercise training program, as previously informed, four instruments were applied to measure FPM strength and functioning in three stages of the program: before, 30 and 60 days after intervention. This procedure is characterized by dependence between repeated measures for each participant.

Therefore, there are three time points and each time point is a level of the independent variable. Thus, the same individual is measured more than once on the same dependent variable and data analysis is performed using repeated measures ANOVA for two types of study design. This analysis is also referred to as within-subject ANOVA or ANOVA for correlated samples. Tukey's t-test was used to compare the means between initial, middle and final evaluations was used.

In order to assess the correlation between the different methods used to evaluate PFM strength, Spearman's rank-order correlation (Spearman's rho) was applied to estimate the monotonic relationship between two continuous or ordinal variables. In a monotonic relationship, the variables tend to change simultaneously, but not necessarily at a constant rate. Spearman's correlation coefficient is based on the RANKED values for each variable, rather than on raw data. A 5\% significance level was used for all tests in this study.

Participants signed the consent form according to Resolution 466/2012 of the Brazilian Ministry of Health. After the study was approved by the Research Ethics Committee of the Faculty of Medical Sciences of Paraíba (Protocol No. 1.535.552), the participants were interviewed and then submitted to functional evaluation of the pelvic floor.

\section{RESULTS}

The sample was composed of 31 female undergraduate students from a private university, $71 \%(\mathrm{n}=22)$ of whom were unmarried, $49 \%(n=15)$ were white, $32 \%(n=10)$ were mulatto and $19 \%(n=06)$ were black.

Table I shows the improvement in FPM performance in all components of the contractile response measured by all four methods at 5\% significance. Note that all variables tended to increase over training, with a statistically significant difference between the condition before and after eight weeks for contraction force (F) and sustained contraction time (E) as well as total PERFECT scores. This same profile was observed for the quantitative results of Peritron, Perina and vaginal cones. The evaluations carried out using only PERFECT strength $(\mathrm{P})$ and Perina revealed more differences between the values obtained before the exercise program and after 4 weeks (Table I).

Table I - Mean values $( \pm$ SD) for FPM variables using the PERFECT, Peritron and Perina perineometer, and vaginal cone methods, in phases 1, 2 and 3. João Pessoa, Brazil, 2016.

\begin{tabular}{lcccc}
\hline PFM evaluation instruments & Phase 1 & Phase 2 & Phase 3 & p-values \\
\hline PERFECT (total) & $17.87^{\mathrm{b}} \pm 1.43$ & $26.52^{\mathrm{a}} \pm 1.69$ & $28.29^{\mathrm{a}} \pm 1.56$ & $<0.001$ \\
$\mathrm{P}(0-5)$ & $2.45^{\mathrm{b}} \pm 0.85$ & $3.03^{\mathrm{a}} \pm 0.87$ & $3.06^{\mathrm{a}} \pm 0.99$ & 0.011 \\
$\mathrm{E}(\mathrm{s})$ & $4.26^{\mathrm{c}} \pm 2.72$ & $5.90^{\mathrm{ab}} \pm 2.89$ & $6.77^{\mathrm{a}} \pm 2.96$ & 0.003 \\
\hline PERITRON $\left(\mathrm{cm} \mathrm{H}_{2} \mathrm{O}\right)$ & $67.02^{\mathrm{b}} \pm 4.70$ & $72.93^{\mathrm{ab}} \pm 3.58$ & $79.81^{\mathrm{a}} \pm 3.45$ & $<0.001$ \\
PERINA $\left(\mathrm{mm} \mathrm{H}_{2} \mathrm{O}\right)$ & $24.39^{\mathrm{b}} \pm 2.37$ & $32.19^{\mathrm{a}} \pm 1.91$ & $35.94^{\mathrm{a}} \pm 1.61$ & $<0.001$ \\
VAGINAL CONES $(\mathrm{G})$ & $11.29^{\mathrm{b}} \pm 2.69$ & $18.39^{\mathrm{ab}} \pm 3.31$ & $23.87^{\mathrm{a}} \pm 3.58$ & $<0.001$ \\
\hline
\end{tabular}

Equal letters mean that no statistical differences were found at $5 \%$

Table II shows significant positive correlations between the assessment' instruments used in this study. The functional evaluations of PFM using digital palpation (PERFECT scheme) showed good ability to estimate the contraction parameters of force $(\mathrm{P})$ and endurance $(\mathrm{E})$. Higher correlations were found between total scores for PERFECT $\times$ Perina $(\mathrm{rho}=0.697 ; \mathrm{p}<$ 0.001), E (PERFECT x Perina) (rho=0.688; $\mathrm{p}<0.001)$, P (PERFECT $\times$ Peritron) $(r h o=0.506 ; \mathrm{p}<0.001)$, Perina $\times$ Peritron $(\mathrm{rho}=$ $0.530 ; \mathrm{p}<0.01)$ and $\mathrm{E}$ (PERFECT $\mathrm{x}$ vaginal cones) $(\mathrm{rho}=0.571 ; \mathrm{p}<0.001)$. The lower correlation values occurred between the total values for PERFECT x Peritron (rho=0.389; $<0.001)$, and P (PERFECT x vaginal cones) $(\mathrm{rho}=0.361 ; \mathrm{p}<0.001)$. 
Table II - Correlation between pelvic floor muscle assessment tools according to Spearman's correlation coefficients and their p-values. João Pessoa, Brazil, 2016.

\begin{tabular}{lcc}
\hline Correlation between variables & $\begin{array}{c}\text { Coefficient } \\
\text { (Spearman rho) }\end{array}$ & p-value \\
\hline PERFECT X Peritron & 0.389 & $<0.001$ \\
Perina x Peritron & 0.530 & $\leq 0.001$ \\
Vaginal cones x Peritron & 0.492 & $\leq 0.001$ \\
Perina x PERFECT & 0.697 & $\leq 0.001$ \\
Vaginal cones x PERFECT & 0.563 & $<0.001$ \\
Vaginal cones x Perina & 0.618 & $<0.001$ \\
P (PERFECT) x Peritron & 0.506 & $<0.001$ \\
P (PERFECT) x Perina & 0.527 & $<0.001$ \\
P (PERFECT) x Vaginal cones & 0.361 & $<0.001$ \\
E (PERFCT) x Peritron & 0.412 & $<0.00$ \\
E (PERFECT) x P (Perfect) & 0.602 & $<0.001$ \\
E (PERFECT) x Perina & 0.688 & $<0.001$ \\
E (PERFECT) x Vaginal cones & 0.571 & $<0.001$ \\
\hline
\end{tabular}

\section{DISCUSSION}

There are several methods for quantifying PFM functionality through digital palpation with the aid of devices that measure pressure and muscle strength. Pelvic floor muscle contraction training depends on understanding the exercise commands given and awareness of the location of these muscles. In addition, training must include acceptance, motivation and inclusion of longterm contraction exercises ${ }^{(12,17)}$.

The PFM training programs should be based on awareness and learning programs as well as home exercises because treatment can be faster and have better results when the patient adhere to and understand the purpose of the treatment, making the patients more secure and confident to perform tasks from day to day ${ }^{(18)}$.

The results of the present study demonstrated good correlation between digital palpation and the biofeedback method using Perina as well as vaginal cones for the endurance response (E) in relation to PERFECT. There was a high positive correlation between digital palpation detection of muscular strength (P) using PERFECT and Peritron. Thus, both $\mathrm{P}$ and $\mathrm{E}$ variables of PERFECT could be used for diagnosis and long-term monitoring of PFM when perineometers are not available.

The PERFECT method of evaluation through palpation has shown to be reliable and reproducible for individual rehabilitation. This method evaluates strength and endurance, allowing a more specific approach ${ }^{(4)}$. The assessment of PFM is essential for the development of appropriate treatment and for monitoring the results of PFD. The International Continence Society suggests that the functional evaluation of the pelvic floor should be performed through visual inspection, digital palpation, perineometry or electromyography ${ }^{(19)}$.

Therapeutic PFM exercises play an important role in improving functionality, since they favor harmonization and education of these muscles through isolated contractions of muscles associated with pelvis positioning and proper breathing ${ }^{(()}$. Moreover, these exercises require different positions to recruit specific muscles, enhancing women's control and awareness of them ${ }^{(7)}$.

Furthermore, it is important to emphasize the principle of overload, i.e., a muscle system should be exercised at a level beyond which a training effect occurs. After a certain period, exercise fails to promote muscle gain, making it necessary to modify the stimulus ${ }^{(20)}$. Corroborating these authors, the present study found the best gain in PFM strength between the initial and final steps, that is, after 8 weeks of intervention when compared to the gain after 4 weeks; this result was observed for all measuring methods applied.

In a clinical study ${ }^{(21)}, 23$ postpartum multiparous women with mean age of $25.3 \pm 4$ years $(p=0.4)$ were divided into two groups: an intervention group $(\mathrm{n}=11)$ with an 8 -week PFM exercise program and a control group $(\mathrm{n}=12)$. In the aforementioned study, PFM strength was assessed by digital vaginal palpation and perineometer (Perina), with a good correlation between both procedures. The authors found no significant post-exercise differences between the groups in either measure of muscle strength $(\mathrm{p}<0.001)$. In this case, the two muscle strength measurement methods were significantly correlated in both assessments (1st assessment: $\mathrm{r}=0.889, \mathrm{p}<0.001 ; 2 \mathrm{nd}$ assessment: $\mathrm{r}=0.925, \mathrm{p}<0.001)^{(21)}$. The authors observed that vaginal palpation can be used in clinical practice to measure PFM strength, since it is low cost and showed good correlation with perineometer assessment. The authors further emphasize that the exercise program resulted in a significant increase in PFM strength in postpartum women and contributed to the prevention of urinary incontinence ${ }^{(21)}$. 
To assess PFM functional strength and contraction capacity using electromyography and biofeedback (Perina), a study carried out a one-year experiment with professional female athletes divided into two groups (volleyball, $\mathrm{n}=10$; basketball, $\mathrm{n}=10$ ). The results showed that both digital palpation and electromyographic biofeedback exhibited good PFM contraction capacity ${ }^{(22)}$. Current research has also shown that digital palpation is an effective evaluation tool for measuring the strength of PFM.

The studies cited above ${ }^{(21,22)}$ corroborate that assessing PFM is important to maintain perineal muscle contraction, which is functionally critical for supporting pelvic organs in addition to generating and maintaining positive female urethral pressure, avoiding incontinence and sexual dysfunction.

Another interesting finding regarding the influence of digital palpation on PFM strength was described in a study to evaluate the effect of pelvic floor exercises on the muscular strength of the pelvic floor through ultrasound, PERFECT method and perineometers. A total of 116 patients with urinary incontinence were randomly assigned to a pelvic floor muscle training group $(n=65)$ or control group $(n=51)$. According to the study, there was a positive correlation between the PERFECT force measurement scale and the ultrasound force measurement scale before and after the intervention in the control muscle and pelvic floor training groups $(r=0.632 \text { and } r=0.642 \text {, respectively })^{(23)}$.

The findings of the present research, in which the efficacy of the digital palpation method PERFECT was evident, indicate that PFM assessment using vaginal palpation can be applied in clinical practice, since it is a low-cost method significantly correlated to more objective methods, such as perineometers and ultrasound. In the present study, the results observed with the PERFECT scheme were significantly correlated with those obtained using perineometer devices.

The results of the present study indicated that vaginal cones, which are easy to use and allow self-assessment, also correlated significantly to contraction time obtained by the "E" component of the PERFECT method. Thus, all the methods exhibited advantages and are successfully used in clinical practice. In cases where perineometers are not available, digital palpation seems to be a very good option, as demonstrated by its accuracy, which is highly correlated to data obtained by perineometers or vaginal cones. The digital palpation method was also an efficient method to monitor the positive effects of pelvic muscle strength produced by an 8-week exercise program. With respect to the importance of functional PFM for the quality of life of women, the availability of a useful technique is essential to delay comorbidities associated in older people, such as urinary incontinence and/or sexual dysfunction.

Discussing issues related to women and sexuality is talking about a problem that has not yet been adequately addressed, despite all women's sexual freedom and gradual achievements over the past 40-45 years. Women's health is addressed in Brazilian public health policies, but without focusing on the sexual function of women. Nevertheless, female sexual dysfunction is a public health problem that significantly affects the quality of life of women. Therefore, it is necessary to address sexuality issues in the consultations and in the elaboration of a complete diagnosis that allows multidisciplinary intervention based on the singularity of each case. Difficulties in the criteria for defining female sexual dysfunction are also found, since in most cases the sexual experience of women depends much more on the social context than on the physiology of the genitals. Taking into account that life expectancy has increased in the general population, with the highest increase among women, it is important to emphasize that talking about sexuality is also important for high rates quality of life. Thus, the problems related to this issue go beyond the treatment, which, when not resolved, may even evolve into anxiety and depression. It is clear then that the benefits of physical therapy in the treatment of these dysfunctions should be disclosed to the health services so that women who suffer for not having a satisfactory sex life can receive the necessary information. It should be emphasized that the understanding of the treatment should also consider that the patients need to be an active part of the therapeutic process, which considerably increases the effectiveness of the treatment and its respective success.

\section{CONCLUSION}

There are several ways to evaluate pelvic floor muscles function and promote sensory feedback to the patient. The PERFECT method allows quantification of the intensity, the number of contractions, both fast and slow, as well as the duration of contraction of the perineal musculature. In addition to being a cheap method, it has been sensitive and specific to the objective in focus. With regard to the low costs of digital palpation, the introduction of this technique into women's health services is likely to improve women's quality of life.

\section{ACKNOWLEDGEMENTS}

We would like to thank the participants and the support from CNPq, Proc. No. 306018/2013-6 and Proc. No. 484972/20138 to $\mathrm{MBCS}$. 


\section{REFERENCES}

1. Faiena I, Patel N, Parihar JS, Calabrese M, Tunuguntla H. Conservative Management of urinary incontinence in women. Rev Urol. 2015;17(3):129-39.

2. Bortolami A, Vanti C, Banchelli F, Guccione AA, Pillastrini P. Relationship between female pelvic floor dysfunction and sexual dysfunction: an observational study. J Sex Med. 2015;12(5):1233-41.

3. Fortunato GL, Aliberte PI, Angelin ECN, Gruber CR. Correlação entre a força dos músculos do assoalho pélvico e a satisfação sexual de mulheres. Cad Escola Saúde. 2011;2(6):143-58.

4. Silva AL Filho, Fonseca AMRM, Camillato ES, Cangussu RO. Análise dos recursos para reabilitação da musculatura do assoalho pélvico em mulheres com prolapso e incontinência urinária. Fisioter Pesqui. 2013;20(1):90-6.

5. Bezerra KC, Vasconcelos JA Neto, Bezerra LRPS, Karbage SAL, Frota IPR, Vasconcelos CTM. Health promotion to patients with pelvic floor dysfunction: an integrative review. Open J Obst Gynecol. 2015;5(3):155-62.

6. Pivetta HMF, Braz MM, Real AA, Nascimento JR, Cabeleira MEP, Veye APZ. Disfunções do assoalho pélvico em pacientes submetidas à histerectomia: um estudo de revisão. Cinergis. 2014;15(1):48-52.

7. Bertoldi JT, Medeiros AM, Goulart SO. The method pilates effects on pelvic floor of climacteric women: a case of study. Cinergis. 2015;16(4):255-60.

8. Fitz FF, Stüpp L, Costa TF, Sartori MGF, Girão MJBC, Castro RA. Correlation between maximum voluntary contraction and endurance measured by digital palpation and manometry: An observational study. Rev Assoc Médica Brasileira. 2016;62(7):635-40.

9. Laycock J, D Jerwood D. Pelvic floor muscle assessment: the perfect scheme. Physiotherapy. 2001;87(12):631-42.

10. Bø K. Pelvic floor muscle training in treatment of female stress urinary incontinence, pelvic organ prolapse and sexual dysfunction. World J Urol. 2012;30(4):437-43.

11. Micussi MT, Freitas RP, Angelo PH, Soares EM, Lemos TM, Maranhão TM. Evaluation of the relationship between the pelvic floor muscles and insulin resistance. Diabetes Metab Syndr Obes. 2015;28(8):409-13.

12. Bø K, Sherburn M. Evaluation of female pelvic floor muscle function and strength. Phys Ther. 2005;85(3):269-82.

13. Herderschee R, Hay-Smith EJ, Herbison GP, Roovers JP, Heineman MJ. Feedback or biofeedback to augment pelvic floor muscle training for urinary incontinence in women. Cochrane Database Syst Rev. 2011; 6(7):CD009252.

14. Kegel AH. Progressive resistance exercise to the functional restoration of the perineal muscles. Am J Obstet Gynecol. $1948 ; 56(2): 238-48$.

15. Tithi Gadhavi MPT. Effect of Tanzberger Exercise Versus Kegel Exercise on Pelvic Floor Muscle Strength In Postmenopausal Women With Stress incontinence- An experimental study. Int J Recent Sci Res. 2017;8(1):15427-33.

16. Ayeleke RO, Hay-Smith EJC, Omar MI. Pelvic floor muscle training added to another active treatment versus the same active treatment alone for urinary incontinence in women (review). Cochrane Database Syst Rev. 2013(11):CD010551.

17. Martinho NM, Silva VR, Marques J, Carvalho LC, Iunes DH, Botelho S. The effects of training by virtual reality or gym ball on pelvic floor muscle strength in postmenopausal women: a randomized controlled trial. Braz J Phys Ther. 2015;20(3):248-57.

18. Alencar PDC, Ventura PL. Benefícios do treinamento da musculatura do assoalho pélvico no tratamento de mulheres com incontinência urinária de esforço: revisão de literatura. Rev Interd Ciênc Saúde. 2015;2(3):38-46.

19. Pereira VS, Hirakawa HS, Oliveira AB, Driusso P. Correlação entre palpação digital, pressão de contração, atividade eletromiográfica e variáveis ultrassonográficas da musculatura do assoalho pélvico feminino. Braz J Phys Ther. 2014;18(5):428-34.

20. Marques M, Stothers L, Macnab A. The status of pelvic floor muscle training for women. Can Urol Assoc J. 2010;4(6):41924.

21. Assis TR, Sá ACAM, Amaral WN, Batista EM, Formiga CKMR, Conde DM. The effect of an exercise program to strengthen pelvic floor muscles in multiparous women. Rev Bras Ginecol Obstet. 2013;35(1):10-5.

22. Reis AO, Camara CNS, Santos SGAD, Dias TS. Comparative study of the capacity of pelvic floor contraction in volleyball and basketball athletes. Rev Bras Med Esporte. 2011;17(2):97-101. 
23. Tosun OC, Solmaz U, Ekin A, Tosun G, Gezer C, Ergenoglu AM, et al. Assessment of the effect of pelvic floor exercises on pelvic floor muscle strength using ultrasonography in patients with urinary incontinence: a prospective randomized controlled trial. J Phys Ther Sci. 2016;28(2):360-5.

\section{First author's address:}

Christiane Kelen Lucena da Costa

Av. General Edson Ramalho, 589

Bairro: Manaíra

CEP: 58038-100 - João Pessoa - PB - Brasil

E-mail: christianekelen@asper.edu.br

\section{Mailing address:}

Maria Bernardete Cordeiro de Sousa

Instituto do Cérebro - Universidade Federal do Rio Grande do Norte - UFRN

Av. Nascimento de Castro, 1255

Bairro: Lagoa Nova

CEP: 59056-450 - Natal - RN - Brasil

E-mail: mbcsousa@gmail.com 